\title{
PENGARUH FDR DAN CAR TERHADAP PENYALURAN PEMBIAYAAN DENGAN ROA SEBAGAI VARIABEL INTERVENING
}

\author{
Aulia Nurlaili Kusuma Wardani ${ }^{1)}$, Arifin ${ }^{2)}$ \\ Fakultas Ekonomi dan Bisnis, Universitas Muhammadiyah Pringsewu \\ Email: aulianurlailikw@umpri.ac.id
}

\begin{abstract}
Abstrak
Operasional Bank dilihat dari kinerja keuangan baik penghimpunan ataupun penyaluran. Perbankan Syariah merupakan lembaga yang menghimpun dana dari pihak ketiga atau masyarkat untuk kegiatan operasional dalam bentuk simpanan dan penyaluranan pembiayaan. Tujuan penelitian ini untuk mengetahui pengaruh Finance to Deposit Ratio (FDR) dan Capital Adequacy Ratio (CAR) terhadap penyaluran pembiayaan serta pengaruh tidak langsungnya melalui Return On Assets (ROA) pada Bank Syariah Mandiri 2016-2020. Penelitian ini menggunakan metode kuantitatif. Populasi pada penelitian ini adalah Bank Syariah Mandiri tahun 2014-2018. Teknik sampling menggunakan metode purposive sampling. Variabel dependen dalam penelitian ini adalah penyaluran pembiayaan $(\mathrm{Y})$ dan variabel independen adalah FDR dan CAR, dengan variabel mediasi adalah ROA (Z). Alat analisis yang digunakan adalah analisis path. Hasil penelitian menunjukkan bahwa FDR berpengaruh terhadap ROA dan CAR tidak berpengaruh terhadap ROA. Untuk FDR dan CAR berpengaruh terhadap penyaluran pembiayaan dan ROA tidak berpengaruh terhadap penyaluran pembiayaan. ROA sebagai variabel intervening tidak dapat memediasi hubungan antara FDR dan CAR terhadap penyaluran pembiayaan.
\end{abstract}

Kata Kunci: FDR, CAR, Penyaluran Pembiayaan, ROA

\section{PENDAHULUAN}

Perbankan merupakan industri penggerak perekonomian suatu negara. Bank disebut sebagai badan usaha yang menghimpun dana dari masyarakat dalam bentuk simpanan dan menyalurkan kepada masyarakat dalam bentuk kredit atau bentukbentuk lainnya dalam rangka meningkatkan taraf hidup masyarakat (Undang-undang nomor 10 tahun 1998). Di Indonesia terdapat dua jenis lembaga perbankan, yakni konvensional dan syariah. Perbankan syariah dalam melakukan kegiatan operasionalnya menerapkan prinsip bagi hasil dan risiko (profit and loss sharing). Sebagai bagian dari sistem perbankan nasional, Bank Syariah mempunyai peranan 
yang penting dalam perekonomian. Peranan perbankan Syariah dalam aktivitas ekonomi Indonesia tidak jauh berbeda dengan perbankan konvensional (Ulfa, 2012).

Bank berdasarkan prinsip syariah atau bank syariah, seperti halnya bank konvensional juga berfungsi sebagai suatu lembaga intermediasi keuangan (financing intermediary institution), yaitu suatu lembaga yang kegiatannya menghimpun dan dari masyarakat dalam bentuk simpanan dan menyalurkannya kembali dana-dana tersebut kepada masyarakat yang membutuhkannya dalam bentuk fasilitas pembiayaan (Lestari, 2012). Menurut Undang-Undang Republik Indonesia Nomor 10 Tahun 1998, pembiayaan berdasarkan Prinsip Syariah adalah penyediaan uang atau tagihan yang dipersamakan dengan itu berdasarkan persetujuan atau kesepakatan antara bank dengan pihak lain yang mewajibkan pihak yang dibiayai untuk mengembalikan uang atau tagihan tersebut setelah jangka waktu tertentu dengan imbalan atau bagi hasil.

Rasio likuiditas bank merupakan rasio yang digunakan untuk mengukur kemampuan bank dalam memenuhi kewajiban jangka pendeknya pada saat ditagih (Kasmir, 2015). Rasio yang berhubungan dengan likudiitas adalah Financing to Deposit Ratio (FDR). Semakin tinggi Financing to Deposit Ratio (FDR) maka semakin meningkat laba bank (dengan asumsi bank tersebut mampu menyalurkan kreditnya dengan efektif). Namun semakin rendah Financing to Deposit Ratio (FDR) menunjukkan bahwa bank kurang efektif dalam menyalurkan kredit sehingga dapat menurunkan laba bank.

Undang-Undang No. 10 Tahun 1998 pasal 29 ayat 2 menyatakan bahwa setiap bank di Indonesia wajib memelihara tingkat kesehatan bank sesuai dengan kecukupan modal dan aspek lain yang berhubungan dengan usaha bank, dan bank juga diwajibkan untuk menerapkan prinsip kehati-hatian dalam menjalankan kegiatan usahanya. Capital Adequacy Ratio (CAR) merupakan rasio yang berkaitan dengan faktor permodalan, yang berfungsi untuk mengukur kecukupan modal yang dimiliki bank. Semakin tinggi rasio CAR berarti menunjukkan bahwa semakin kuat kemampuan lembaga keuangan tersebut untuk menanggung resiko dari setiap pembiayaan atau aktiva produktif yang beresiko serta memberikan kontribusi yang cukup besar terhadap profitabilitas (Kuncoro dan Suhardjono, 2002) 
Menurut Syamsudin (2016: 63), bahwa "Return on Assets merupakan pengukuran kemampuan perusahaan secara keseluruhan didalam menghasilkan keuntungan dengan jumlah keseluruhan aktiva yang tersedia di dalam perusahaan”. Semakin tinggi rasio ini, semakin baik keadaan suatu perusahaan. Penting bagi para nasabah untuk mengetahui kinerja dari suatu bank terutama yang menggunakan jasa atau layanan bank tersebut. Kinerja bank syariah sangat ditentukan oleh kualitas dari penanam dana atau pembiayaan yang pada akhirnya mempengaruhi tingakat Return On Assets (ROA).

Adapun Gap Research pada penelitian ini dikemukakan pada peneliti sebelumnya seperti pada penelitian yang dilakukan oleh Nia Noorfitri Handayani (2015) menghsilkan bahwa CAR memiliki pengaruh signifikan terhadap penyaluran pembiayaan. Menurut penelitian Indarti dan Arini (2020) menyatakan bahwa Finance to Deposit Ratio (FDR) dan Capital Adequac Ratio (CAR) tidak ada pengaruh terhadap pembiayaan mudharabah. Menurut Yulia dan Khofid (2020) Financing to Deposit Ratio (FDR) berpengaruh positif terhadap peningkatan penyaluran pembiayaan. Menurut Nadi, dkk (2020) FDR dan CAR mempunyai pengaruh positif dan signifikan terhadap ROA. Menurut Muhammad dan Mahfud Capital Adequac Ratio (CAR) berpengaruh negatif tidak signifikan terhadap variabel ROA dan FDR berpengaruh positif tidak signifikan terhadap variabel ROA.

\section{METODE PENELITIAN}

Desain penelitian yang digunakan adalah penelitian kuantitatif deskriptif. Penelitian ini dilakukan guna untuk melihat pengaruh variable melalui pengujian hipotesis berdasarkan data yang diperoleh dari annual report Bank Syariah Mandiri. Populasi penelitian ini adalah Bank Umum Syariah yang terdaftar di Bursa Efek Indonesia periode 2014-2018. Sampel penelitian ini adalah Bank Syariah Mandiri periode 2014-2018. Sedangkan teknik pengumpulan data yang digunakan dalam penelitian ini menggunakan teknik dokumentasi. Dokumentasi adalah data yang dikumpulkan dengan melihat dokumen atau catatan-catatan yang relevan dengan masalah (Arikunto, 2002). Teknik ini digunakan untuk mendokumentasikan data yang diperlukan dalam penelitian yaitu laporan keuangan Bank Syariah Mandiri. 
ISSN Cetak : 2087-0434

E-ISSN : :2599-0810

Analisis data dalam penelitian ini menggunakan analisis jalur (path analysis). Penelitian ini untuk mengeatui apakah ROA berpengaruh mediasi pada FDR dan CAR terhadap Penyaluran Pembiayaan. Analisis dalam jalur digunakan untuk menganalisis data yang diperoleh, karena dari model yang disusun terdapat keterkaitan hubungan antara sejumlah variabel yang dapat diestimasi secara simultan. Selain itu variabel dependen pada satu hubungan yang sudah ada, akan menjadi variabel independen pada hubungan selanjutnya (Aisyah 2010).

Untuk uji mediasi menggunakan uji sobel. Uji mediasi dapat dilakukan dengan prosedur yang dikembangkan oleh Sobel dan dikenal dengan uji sobel (Ghazali, 2016). Uji sobel dilakuakn dengan cara menguji kekuatan pengaruh tidak langsung $\mathrm{X}$ ke Y melalui Z. Standar eror koefisien a dan b ditulis dengan $S_{a}$ dan $S_{b}$ dan besarnya standar error pengaruh tidka langsung (indirect effect) adalah $\mathrm{S}_{\mathrm{ab}}$ yang dihitung dengan rumus sebagai berikut :

$s a b=\sqrt{b^{2} s a^{2}+a^{2} s b^{2}+s a^{2} s b^{2}}$

Untuk menguji signifikan pengaruh tidak langsung, maka kita perlu menghitung nilai $t$ dari koefisien ab dengan rumus sebagai berikut :

$t=\frac{a b}{s a b}$

HASIL DAN PEMBAHASAN

Tabel 1

Mean, ST Deviasi, Minimum Maksimum

\begin{tabular}{lllll}
\hline & FDR & CAR & Pembiayaan & ROA \\
\hline Mean & 100.5842 & 17.2610 & 17.7448 & .7305 \\
St Deviasi & 10.75145 & 2.43272 & .20980 & .50690 \\
Minimum & 76.02 & 7.56 & 17.19 & .11 \\
Maksimum & 113.45 & 20.97 & 18.01 & 2.01 \\
$\mathbf{N}$ & 60 & 60 & 60 & 60 \\
\hline
\end{tabular}


ISSN Cetak : 2087-0434

E-ISSN : :2599-0810

Pada tabel 1, output spss menunjukkan variabel independen dalam penelitian ini adalah Financing to Deposit Ratio (FDR) dari dana pihak ketiga dibagi dengan penyaluran pembiayaan yang menunjukkan nilai minimum sebesar 76.02, maximum sebesar 113.45, rata-rata (mean) sebesar 100.5842 dengan standar deviasi 10.75145 . Variabel Capital Adequacy Ratio (CAR) dari modal dibagi dengan ATMR menunjukkan nilai minimum sebesar 7.56, maximum sebesar 20.97, rata-rata (mean) sebesar 17.2610 dengan standar deviasi 2.43272 .

Variabel dependen dalam penelitian ini adalah penyaluran pembiayaan menunjukkan nilai minimum sebesar 17.19, maximum sebesar 18.01, rata-rata (mean) sebesar 17.7448 dengan standar deviasi 0.20980. Variabel intervening dalam penelitian ini adalah Return on Asset (ROA) menunjukkan nilai menunjukkan nilai minimum sebesar 0.11, maximum sebesar 2.01, rata-rata (mean) sebesar 0.7305 dengan standar deviasi 0.50690

Tabel 2

Hasil Analisis Regresi: Pengaruh $\mathrm{X}_{1}, \mathrm{X}_{2}$, terhadap $\mathrm{Z}$

\begin{tabular}{lccc}
\hline Variabel Bebas & Standardized Coefficients Beta & $\mathrm{T}$ & Sig. \\
\hline Constanta & -0.986 & $-1,263$ & 0,212 \\
$F D R\left(\mathrm{X}_{1}\right)$ & 0.431 & 3,612 & 0,001 \\
$C A R\left(\mathrm{X}_{2}\right)$ & -0.096 & $-1,263$ & 0,423 \\
Variabel terikat = ROA & & \\
$\mathrm{R}$ & $=0,457$ & \\
$\mathrm{R}$ Square $\left(\mathrm{R}^{2}\right)$ & $=0,209$ & \\
$\mathrm{~S}_{\mathrm{e}}$ & $=0,766$ & \\
$\mathrm{~F}_{\text {hitung }}$ & $=7,518$ & \\
$\mathrm{~F}_{\text {tabel }}$ & $=3,15$ & \\
Sig & $=0,001$ & \\
\hline
\end{tabular}

Dari tabel 2 diatas, maka dapat diperoleh model persamaan pertama sebagai berikut:

$Z=-0,968+0,431 X 1-0,096 \times 2$

$\mathrm{R}^{2}=0,209$ berarti $20,9 \%$ variasi ROA dijelaskkan oleh variabel Finance to Deposit Ratio dan Capital Adequacy Ratio. Untuk nilai standar error estimate $\left(\mathrm{S}_{\mathrm{e}}\right)$, bila semakin kecil nilai $S_{\mathrm{e}}$ maka akan membuat model regresi semakin tepat memprediksi variabel independen. 
Tabel 3

Hasil Analisis Regresi: Pengaruh $\mathrm{X}_{1}, \mathrm{X}_{2}, \mathrm{Z}$ terhadap $\mathrm{Y}$

\begin{tabular}{llll}
\hline Variabel Bebas & Standardized Coefficients Beta & $\mathrm{T}$ & Sig. \\
\hline Constanta & 16.288 & 53,562 & 0,000 \\
$F D R\left(\mathrm{X}_{1}\right)$ & 0.500 & 3,991 & 0,000 \\
$C A R\left(\mathrm{X}_{2}\right)$ & 0.368 & 3,241 & 0,002 \\
$R O A(\mathrm{Z})$ & -0.235 & $-1,878$ & 0,066 \\
Variabel terikat = Penyaluran Pembiayaan & & \\
$\mathrm{R}$ & $=0,552$ & & \\
$\mathrm{R}$ Square $\left(\mathrm{R}^{2}\right)$ & $=0,267$ & & \\
$\mathrm{~S}_{\mathrm{e}}$ & $=0,304$ & & \\
$\mathrm{~F}_{\text {hitung }}$ & $=8,177$ & & \\
$\mathrm{~F}_{\text {tabel }}$ & $=3,15$ & & \\
Sig & $=0,000$ & & \\
& & & \\
& &
\end{tabular}

Dari tabel 3 diatas, maka dapat diperoleh model persamaan pertama sebagai berikut: $\mathrm{Y}=16,288+0,500 \mathrm{X} 1+0,368 \mathrm{X} 2-0,235 \mathrm{Z}$

$\mathrm{R}^{2}=0,267$ berarti $26,7 \%$ variasi nilai perusahaan dijelaskan oleh variabel Finance to Deposit Ratio, Capital Adequaccy Ratio, dan Return On Assets. Untuk nilai standar error estimate $\left(\mathrm{S}_{\mathrm{e}}\right)$, bila makin kecil nilai $\mathrm{S}_{\mathrm{e}}$ maka akan membuat model regresi semakin tepat memprediksi variabel independen.

Pengaruh FDR $\left(\mathrm{X}_{1}\right), C A R\left(\mathrm{X}_{2}\right)$, dan $R O A(\mathrm{Z})$ terhadap penyaluran pembiayaan (Y).

\section{a. Hasil Perhitungan Koefisien Path}

Adapun hasil perhitungan koefisien path adalah sebagai berikut:

$$
\begin{aligned}
\operatorname{PTL}(\mathrm{X}-\mathrm{Y}) & =(0,431-0,096) \times(-0,235) \\
& =0.335 \times(-0,235) \\
& =-0.0787
\end{aligned}
$$

\section{b. Hasil Pemeriksaan Validitas Model}

Berdasarkan tabel 2 dan 3, dapat disusun model lintasan pengaruh yang disebut analisis path. Pengaruh error pada persamaan pertama dan kedua adalah sebagai berikut: 


$$
\begin{array}{lc}
P e=\sqrt{1-R^{2}} & R m^{2}=1-P e_{1}{ }^{2}-P e_{2}{ }^{2} \\
P e_{1}=\sqrt{1-0,209}= & =1-(0,989)^{2}(0.733)^{2} \\
0,989 & =0,475 \\
P e_{2}=\sqrt{1-0,267}= & \\
0,733 &
\end{array}
$$

Pemeriksaan validitas model melalui koefisien determinasi total $\left(\mathrm{Rm}^{2}\right)$ menunjukkan nilai sebesar 47, 5\%. Jadi total keragaman data yang dapat dijelaskan oleh model adalah sebesar $47,5 \%$.

\section{c. Hasil Pengujian Hipotesis 1}

Finance to Deposit Ratio $\left(\mathrm{X}_{1}\right)$ mempunyai nilai $\mathrm{t}_{\text {hitung }}=3,612$ dan $\mathrm{t}_{\text {tabel }}=3,15$. Probabilitas sebesar 0,001 lebih kecil dari 0,05 dan nilai $t_{\text {hitung }}>t_{\text {tabel }}$. Maka dapat disimpulkan bahwa variabel $\mathrm{X}_{1}$ berpengaruh signifikan terhadap ROA. Hal ini berarti $\mathrm{H}_{0}$ ditolak.

Capital Adequacy Ratio $\left(\mathrm{X}_{2}\right)$ mempunyai nilai $\mathrm{t}_{\text {hitung }}=-0,807$ dan $\mathrm{t}_{\text {tabel }}=$ 3,15. Probabilitas sebesar 0,423 lebih besar dari 0,05 dan nilai $t_{\text {hitung }}>t_{\text {tabel }}$. Maka dapat disimpulkan bahwa variabel $\mathrm{X}_{2}$ tidak berpengaruh signifikan terhadap ROA. Hal ini berarti $\mathrm{H}_{0}$ diterima.

\section{d. Persamaan Kedua (menguji hipotesis 2)}

Finance to Deposit Ratio $\left(\mathrm{X}_{1}\right)$ mempunyai nilai $\mathrm{t}_{\text {hitung }}=3,991$ dengan tingkat signifkansi 0,000 dan $t_{\text {tabel }}=3,15$ dan nilai $t_{\text {hitung }}>t_{\text {tabel. }}$. Maka dapat disimipulkan bahwa $\mathrm{X}_{1}$ berpengaruh signnifikan terhadap penyaluran pembiayaan. Hal ini berarti $\mathrm{H}_{0}$ ditolak.

Capital Adequacy Ratio $\left(\mathrm{X}_{2}\right)$ mempunyai nilai $\mathrm{t}_{\text {hitung }}=3,241$ dengan tingkat signifkansi 0,032 dan $t_{\text {tabel }}=3,15$ dan nilai $t_{\text {hitung }}>t_{\text {tabel }}$. Maka dapat disimipulkan bahwa $\mathrm{X}_{2}$ berpengaruh positif dan signnifikan terhadap penyaluran pembiayaan secara langsung. Hal ini berarti $\mathrm{H}_{0}$ ditolak.

Return On Assets (Z) mempunyai nilai $t_{\text {hitung }}=-1,878$ dengan tingkat signifkansi 0,066 dan $\mathrm{t}_{\text {tabel }}=3,15$ dan nilai $\mathrm{t}_{\text {hitung }}<\mathrm{t}_{\text {tabel }}$. Maka dapat disimipulkan 
bahwa $\mathrm{Z}$ tidak berpengaruh signnifikan terhadap penyaluran pembiayaan secara langsung. Hal ini berarti $\mathrm{H}_{0}$ diterima.

Secara parsial variabel Finance to Deposit Ratio dan Capital Adequacy Ratio yang berpengaruh positif serta signifikan terhadap penyaluran pembiayaan. Sedangkan variabel Return On Assets tidak menunjukkan nilai yang signifikan berdasarkan hasil analisis uji t.

\section{e. Analisis Jalur (Menguji Hipotesis 3)}

Berdasarkan analisis pada persamaan pertama diketahui bahwa hanya sebagian variabel yang berpengaruh signifikan terhadap variabel penyaluran pembiayaan. Pengaruh langsung variabel bebas secara parsial terhadap variabel ROA dan variabel penyaluran pembiayaan dapat dijelaskan sebagai berikut:

a) Analisis Jalur $P_{1}$

Jalur $\mathrm{X}_{1}$ ke $\mathrm{Z}$ adalah jalur $\mathrm{P}_{1}$ dengan nilai Beta $=0,431$ dan tingkat Sign $\mathrm{t}=$ 0,001 (lebih kecil dari 0,05). Hasil tersebut dapat diartikan bahwa variabel $\mathrm{X}_{1}$ berpengaruh (positif) secara signifikan terhadap variabel Return On Assets (Z).

b) Analisis Jalur $\mathrm{P}_{2}$

Jalur $\mathrm{X}_{2}$ ke $\mathrm{Z}$ adalah jalur $\mathrm{P}_{2}$ dengan nilai Beta $=-0,096$ dan tingkat Sign $\mathrm{t}$ $=0,423$ (lebih besar dari 0,05). Hasil tersebut dapat diartikan bahwa variabel $\mathrm{X}_{2}$ tidak berpengaruh (negatif) secara signifikan terhadap variabel Return On Assets (Z).

c) Analisis Jalur $\mathrm{P}_{3}$

Jalur $\mathrm{X}_{1}$ ke $\mathrm{Y}$ adalah jalur $\mathrm{P}_{3}$ dengan nilai Beta $=0,500$ dan tingkat Sign $\mathrm{t}$ $=0,000$ (lebih kecil dari 0,05). Hasil tersebut dapat diartikan bahwa variabel $\mathrm{X}_{1}$ berpengaruh (positif ) secara signifikan terhadap variabel penyaluran pembiayaan (Y). 
d) Analisis Jalur $\mathrm{P}_{4}$

Jalur $\mathrm{X}_{2}$ ke $\mathrm{Y}$ adalah jalur $\mathrm{P}_{4}$ dengan nilai Beta $=0,368$ dan tingkat Sign $\mathrm{t}$ $=0,002$ (lebih kecil dari 0,05). Hasil tersebut dapat diartikan bahwa variabel $\mathrm{X}_{2}$ berpengaruh berpengaruh (positif) secara signifikan terhadap variabel penyaluran pembiayaann (Y).

e) Analisis Jalur $\mathrm{P}_{5}$

Jalur $\mathrm{Z}$ ke $\mathrm{Y}$ adalah jalur $\mathrm{P}_{5}$ dengan nilai Beta $=-0,235$ dan tingkat Sign $\mathrm{t}=$ 0,066 (lebih besar dari 0,05). Hasil tersebut dapat diartikan bahwa variabel $\mathrm{Z}$ tidak berpengaruh (negatif) secara signifikan terhadap variabel penyaluran pembiayaan (Y).

\section{f. Pengaruh Mediasi}

Berdasarkan analisis jalur yang signifikan dapat diketahui pengaruh secara tidak langsung antara variabel bebas secara parsial terhadap variabel $\mathrm{Y}$ melalui $\mathrm{Z}$ sebagai berikut:

a) Pengaruh tidak langsung variabel $X_{1}$ terhadap $Y$ diperoleh dengan cara mengalikan koefisien path pengaruh langsung variabel $\mathrm{X}_{1}$ terhadap $\mathrm{Z}\left(\mathrm{P}_{1}\right)$ dengan koefien path pengaruh variabel $\mathrm{Z}$ terhadap $\mathrm{Y}_{1}\left(\mathrm{P}_{1}\right)$ yaitu $0,431 \mathrm{x}(-$ $0,235)=-0,101285$, hal ini berarti terdapat pengaruh negatif secara tidak langsung variabel $\mathrm{X}_{1}$ terhadap $\mathrm{Y}$ melalui $\mathrm{Z}$ sebesar -0,101285.

b) Pengaruh tidak langsung variabel $\mathrm{X}_{2}$ terhadap $\mathrm{Y}$ diperoleh dengan cara mengalikan koefisien path pengaruh langsung variabel $\mathrm{X}_{2}$ terhadap $\mathrm{Z}\left(\mathrm{P}_{2}\right)$ dengan koefien path pengaruh variabel $\mathrm{Z}$ terhadap $\mathrm{Y}_{1}\left(\mathrm{P}_{2}\right)$ yaitu $-0,096 \mathrm{x}(-$ $0.235)=0,02256$, hal ini berarti terdapat pengaruh positif secara tidak langsung variabel $\mathrm{X}_{2}$ terhadap $\mathrm{Y}$ melalui $\mathrm{Z}$ sebesar 0,02256.

Dari hasil penelitian dapat dihasilkan rumusan uji sobel dengan perhitungan sebagai berikut :

\section{Rumus Persamaan X1 dan X1}

$\mathrm{X} 1 S a b=\sqrt{\left(Z^{2} S X 1^{2}\right)+\left(X 1^{2} S Z^{2}\right)+\left(S X 1^{2} S Z^{2}\right)} \mathrm{X} 2$

$S a b=\sqrt{\left(Z^{2} S X 2^{2}\right)+\left(X 2^{2} S Z^{2}\right)+\left(S X 2^{2}+S Z^{2}\right)}$ 
ISSN Cetak : 2087-0434

E-ISSN : :2599-0810

\section{Hasil Perhitungan Persamaan X1, X2}

$\mathrm{X} 1$

$$
\begin{aligned}
& S a b=\sqrt{\left(\left(-0,235^{2}\right)\left(0,006^{2}\right)\right)+\left(\left(0.431^{2}\right)\left(0,052^{2}\right)\right)+\left(\left(0.006^{2}\right)+\left(0,052^{2}\right)\right)}= \\
& \sqrt{(0,055225 x 0,000036)+(0,185761 x 0,002704)+(0,000036+0,002704)} \\
& \quad=\sqrt{0,00321} \\
& \quad=0,0566
\end{aligned}
$$

$\mathrm{X} 2$

$$
\begin{aligned}
\text { Sab } & =\sqrt{\left(\left(-0,235^{2}\right)\left(0,025^{2}\right)\right)+\left(\left(-0,096^{2}\right)\left(0,052^{2}\right)\right)+\left(\left(0,025^{2}\right)+\left(0,052^{2}\right)\right)} \\
& =\sqrt{(0,055225 x 0,000625)+(0,009216 \times 0,002704)+(0,000625+0,002704)} \\
& =\sqrt{0,0033} \\
& =0,0574
\end{aligned}
$$

\section{Hasil Perhitungan Uji Nilai t Hitung}

$$
\begin{aligned}
& X 1 t=\frac{(0,431) x(-0,225)}{0,0566}=-1,789 \\
& X 2 t=\frac{(-0,096) x(-0.225)}{0,0574}=0.393
\end{aligned}
$$

Berdasarkan rumus dan perhitungan sobel di atas, maka hasil uji pengaruh variabel intervening adalah sebagai berikut :

Tabel 4

\section{Hasil Uji Mediasi}

\begin{tabular}{cccccc}
\hline Variabel & $\begin{array}{c}\text { Pengaruh } \\
\text { Tidak } \\
\text { Langsung }\end{array}$ & $\mathbf{S}_{\text {indirecteffect }}$ & $\mathbf{T}_{\text {hitung }}$ & $\mathbf{T}_{\text {tabel }}$ & Keterangan \\
& $-0,101285$ & 0,1034 & -1.789 & 1,671 & \\
\hline $\mathbf{X}_{\mathbf{1}}$ & 0,02256 & 0,0024 & 0.393 & 1,671 & Tidak \\
& & & & & Signifikan \\
$\mathbf{X}_{\mathbf{2}}$ & & & & & Signifikan \\
& & & & & \\
\end{tabular}

Total Koefisien Mediasi $=\mathbf{- 0 . 0 7 8 7 2 5}$

Dari tabel 4 menunjukkan bahwa secara keseluruhan variabel memiliki nilai $\mathrm{t}_{\text {hitung }}$ lebih kecil dari $\mathrm{t}_{\text {tabel }}$ dengan tingkat signifikansi 0,05 , maka dapat disimpulkan bahwa koefisien mediasi -0.078725 yang berarti bahwa tidak signifikan yang berarti tidak ada pengaruh intervening/mediasi. 
Walaupun tidak signifikan bukan berarti bank untuk mengabaikan CAR dalam menyalrukan pembiayaan karena kecukupan modal, bank sering terganggu karena penyaluran pembiayaan yang berlebihan. Tingginya CAR mengindikasi adanya sumber daya finansial (modal) yang idle. Dalam kondisi ini wajar jika bank bertahan untuk tidak menyalurkan pembiayaan karena kenaikan pembiayaan yang disalurkan menambag aset berisiko sehingga mengharuskan bank menambah untuk memnuhi ketentuan CAR (Pratami 2012)

\section{KESIMPULAN}

Finance to Deposit Ratio (FDR) berpengaruh signifikan terhadap ROA. Capital Adequacy Ratio (CAR) berpengaruh signifikan terhadap ROA. Finance to Deposit Ratio (FDR) tidak berpengaruh signifikan terhadap penyalruan pembiayaan. Capital Adequacy Ratio (CAR) berpengaruh signifikan terhadap penyaluran pembiayaan. Finance to Deposit Ratio (FDR) tidak berpengaruh langsung terhadap penyaluran pembiayaan melalui ROA. Capital Adequacy Ratio (CAR) tidak berpengaruh langsung terhadap penyaluran pembiayaan melalui ROA. Yang artinya ROA tidak memilik berpengaruh mediasi Terhadap FDR, CAR pada Penyaluran Pembiayaan.

\section{DAFTAR PUSTAKA}

Andy Porman Tambunan, 2007, Menilai Harga Wajar saham, Elex Media Komputindo, Jakrata,

Aisyah, Esy Nur, 2010, Analisis Faktor-faktor yang mempengaruhi Kinerja Perusahaan (Studi pada Lembaga BMT Maslahah Mursalah Lil UMmmah di Pasuruan), Tesis (tidak dipublikasikan),Pascasarjana Fakultas Ekonomi Brawijaya Malang.

Arikunto, Suharsimi, 2002, Prosedur Penelitian, Jakarta: Rineka Cipta.

Darmawan, Deni, 2014, Metode Penelitian Kuantitatif, Bandung: PT Remaja Rosdakarya Offset 
ISSN Cetak : 2087-0434

E-ISSN : :2599-0810

Dendawijaya, Lukman, 2005, Manajemen Perbankan, Edisi Kedua. Jakarta: Ghalia Indonesia.

Ghozali, Imam, 2016, Aplikasi Analisis Multivariate dengan Program SPSS, Badan Penerbit Universitas Diponegoro: Semarang.

Indarti Nur Baiti dan Arini WIldaniyati, (2020), Pengaruh FDR, NPF, ROA, CAR Terhadap Pembiayaan Mudharabah (Studi EMpiris Pada Bank Umum SYariah Yang Terdaftar di Bank Indonesia Pada Tahun 2015-2019), JAMER-Unmer Madiun, Vol. 1 No 2.

Kasmir. 2015, Analisis Laporan Keuangan, cetk-8. Jakarta: Rajawali Press

Kuncoro, \& Suhardjono, 2002, Manajemen Perbankan (Teori dan Aplikasi), Edisi Pertama. Yogyakarta: BPFE.

Lestari, Fitri Suci, 2012, Peranan Kinerja Keuangan terhadap Besarnya Pembiayaan Perbankan Syariah di Indonesia. Skripsi. Fakultas Ekonomi Uin Maulana Malik Ibrahim Malang.

Muhammad Faizal Fachri \& Mahfudz, 2021, Analisis Pengaruh CAR, BOPO, NPF, dan FDR Terhadap ROA. Diponegoro Journal Of Management.

Nadi, dkk, 2020, Pengaruh FDR, BOPO, NPF, dan CAR Terhadap ROA pada Bank Syariah Mandiri Periode 2012-2019.

Nia Noorfitri Handayani, 2015, Pengaruh capital adequacy ratio (car), non performing financing (npf), dana pihak ketiga (dpk), sertifikat bank umum syariah (sbis) terhadap penyaluran pembiayaan bank umum syariah periode 2009-2015, UIN Jakarta.

Pratami, Wuri Arianti Novi, 2012, Analisis Pengaruh Dana Pihak Ketiga (DPK), Capital Adequacy Ratio (CAR), Non Performing Financing (NPF) dan Return On Assets (ROA) terhadap Pembiayaan pada Perbankan Syariah, Fakultas Ekonomi Universitas Diponegoro Semarang.

Pratin dan Akhyar Adnan, 2005, Analisis Hubungan, Modal Sendiri, NPL, Prosentase Bagi Hasil dan Markup Keuntungan Terhadap Pembiayaan Pada Perbankan Syariah Studi Kasus Pada Bank Muamalat Indonesia, Sinergi: Kajian Bisnis dan Manajemen.

Sugiyono, 2007, Metode Penelitian Pendidikan : Pendekatan Kuantitatif, Kualitatif, dan R\&D, Bandung: Alfabeta.

Susilo, Sri, 2000, Bank dan Lembaga Keuangan Lainnya. Jakarta: Salemba Empat. 
ISSN Cetak : 2087-0434

E-ISSN : :2599-0810

Syamsuddin, Lukman, 2016, Manajemen Keuangan Perusahaan: Konsep Aplikasi dalam: Perencanaan, Pengawasan, dan Pengambilan Keputusan, Edisi baru, Cetakan ke-13, PT Rajagrafindo Persada, Depok 16956.

Yulia \& Khofid Ramdan, 2020, Pengaruh Dana Pihak Ketiga, Financing To Deposit Ratio, Non Performing Financing Dan Tingkat Suku Bunga Terhadap Penyaluran Pembiayaan. IAIN Pontianak.

Ulfa, Maria. 2012. Analisis Perkembangan Aset Dana Pihak ketiga (DPK) dan Pembiayaan Perbankan Syariah di Indonesia. Skripsi (dipublikasikan). Universitas Gunadarma Depok.

Undang-undang nomor 10 tahun 1998 